\title{
The Albanian Family Characteristics (Socio-Geographic) during the Transition Period (in the Southest Region of Albania)
}

\author{
Associate Professor, Valbona Duri \\ Geography Department, Faculty of Education and Social Sciences, "Eqrem Çabej" University, Gjirokastër \\ Email address: bongjeo@yahoo.com
}

\author{
Doi:10.5901/ajis.2016.v5n3s1p487
}

\section{Abstract}

\begin{abstract}
The evolution of the Albanian family, has had a direct impact not only on the reproductive potential of the population. For this reason its study is necessary. The situation of employment (possibilities or impossibilities for employment), income levels, economical structure and the development, education level, the level of urbanization, gender and age composition of the population the birth rate, family planning, mortality general and specific, emigration, the force of tradition, etc., are the main factors that have determined the socio-geographical characteristic features of Albanian society, during the transition political, economic and demographic period in Albania. -The substitution of the centrally planned socialist economy with the free market. -Economic crisis at the beginning of 1990. -The increase of the unemployment. -The reduction of income. -The family planning policy. -The flow of rural population to the cities. -The abandonment of the villages. -The emigration, -The aging demographic The change of gender ratio (because of male emigration). -The traditional psychology, -The economic insecurity. These are the main factors that brought evident change in the Albanian family performance and characteristics, marriage, divorce rate and civil structure of the population too, in the south of Albania. This region is distinguished too for a clear profile emigration, because of the positioning of the neighboring country, Greece, and the presence of the Greek minority. The reduction of the total number of the families, marriages too, after 1990 in this area, has been analyzed under the influence of economical changes, which have been an important impact on the creation of new families; meanwhile, the index of divorce rate per 1000 inhabitants is increased, compared to 1989. At the end the Albanian families' trend will depend on the performance of economic, social and demographic development in Albania.
\end{abstract}

Keywords: aging demographic, gender ratio, structure of the population, the migration, unemployment.

\section{Introduction}

In Albania, during and after 1990, some political, economic and social changes occurred which greatly influenced the demographic developments. Immigration is one of the most determining factors which brought those changes closely into every Albanian family during this economic transition. Albanian families came from a large unit of two or more pairs (crowns in English), and many family members, while now it is replaced by smaller families (parents) with only two children per family. From 7 children in 1950, down to 5 children in 1970, followed by 4 children in 1980, and down again to 3 children in1990.

The impact of immigration in the country, mostly affecting the young generation followed by a low birth rate (from $31.1 \%$ to $7.0 \% 1960$ (2011), was reinforced by a decline in marriage rates. Another factor to be mentioned was a high increase in divorce rates which contributed greatly to those factors. In comparison to other European countries, the fertility decline came late, but this process was conducted with the highest intensity. This phenomenon is very striking, especially when it comes to a large family unit, reduced to only three family members (two parents plus a child).

\section{The Family Dynamics, the Number of Households and its Structure after 1990.}

The family, with it dimension, number structure and its evolution in time and space, has a direct impact on the reproductive potential of the population. In this regard its study constitutes a necessity.

In its evolution have acted several factors with a diverse nature such are demographic, economic, social, psychological, tradition factors etc.

The study in the dynamics of the number of families in southern Albania shows that this number has increased up to $17.8 \%$, compared to 1989 . After that year (1989), important political and economical changes took place. The socialist system was replaced by a free market economy; state ownership was replaced by private ownership, followed by family 
planning policies, immigration etc.

Dynamics (performance) of the number of families fails to give a complete panorama of the changes that have taken place within it. For this purpose, we have to analyze only the dynamics of the average members per family. According to settlements (urban-rural), this indicator is higher (4.4 members / family) than in the village which result to be 3.7 members per families in the city. The reason is in the high birth rate of the rural population which is motivated or conditioned by the demand for labor as the result of non mechanized agriculture.

Table 1: The number of families in the district of Gjirokastra[ $\left.{ }^{1}\right]$

\begin{tabular}{|c|c|c|c|c|c|}
\hline \multirow{2}{*}{ Units } & 1989 & 1994 & 1999 & 2009 & \multirow{2}{*}{$\begin{array}{c}\text { Change } \\
\text { Average members / } \\
\text { family(1989-2009) }\end{array}$} \\
\cline { 2 - 5 } & $\begin{array}{c}\text { Average } \\
\text { members/family }\end{array}$ & $\begin{array}{c}\text { Average } \\
\text { members/family }\end{array}$ & $\begin{array}{c}\text { Average } \\
\text { members/family }\end{array}$ & $\begin{array}{c}\text { Average } \\
\text { members/family }\end{array}$ & -20.4 \\
\hline District & 4.6 & 4.0 & 4.3 & 4.1 & -7.8 \\
\hline Urban area & 4.2 & 3.6 & 4.0 & 3.7 & -27.9 \\
\hline Rural area & 4.9 & 4.2 & 4.5 & 4.4 & \\
\hline
\end{tabular}

Statistics concluded that increasing of family numbers in southern part of Albania has been slow. This situation is a consequence of the change (decrease) in the number of marriages; increase the number of divorces, declining of birth rate, mobility (immigration) of the population, etc.

\section{Numerical Evolution of Families in Spatial (Land) Distribution}

In spatial terms, the number of families in the city is increases by $46.4 \%$, while in the village was decreased by $27.9 \%$ compared to 1989.

The apparent reduction of families in the village is explained by a higher involvement of this population in the migration to the city, outside the district and abroad.

The phenomenon of family contraction has been greatly noticed mostly in villages where due to migration factors the number of families in the village was drastically decreased, in comparison to the city.

In the countryside, the decrease in the average number of family members resulted from 4.9 members (1989) to 4.4 members (2011), while in the city this indicator has decreased from 4.2 to 3.7 members / family.

Change in size of the family was done in two stages. The first stage was the reduction of large families into small ones followed later by a reduction in having new born children as a result of a lower birth rate. These changes are related to numerous factors such are social and economic ones, as well the rising of urbanization level in the region (urban population), migration of the population outside the region, improvement of women education level etc.

The study of family numbers in territory taken in in consideration in this research study show differences according to the region's districts

During 1990-s, general number of families was decreased in three districts of the region. Tepelena District (-27.2 $\%$ is raged the first according to the reduction level, while $n$ the second place is Përmet District (-26.2\%), followed from Gjirokastër District (-12.3\%), in comperison to 1989.

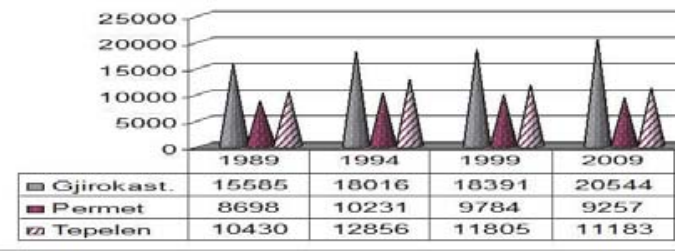

Picture 1: The number of families in Gjirokastra district by district.[2] 
The decrease in the average members / families also appears high in Tepelenë District, the members dropped from 4.9 to 3.9 members. Permet District members dropped from 4.6 to 4.2 members and in Gjirokastra District from 4.4 to 4.0 members / family.

Table 2: Number of families in Gjirokastra district by district

\begin{tabular}{|c|c|c|c|c|c|c|}
\hline \multirow{3}{*}{ Units } & 1989 & 1994 & 1999 & 2001 & 2009 & The change \\
\cline { 2 - 7 } & $\begin{array}{c}\text { Average } \\
\text { members / } \\
\text { family }\end{array}$ & $\begin{array}{c}\text { Average } \\
\text { members / } \\
\text { family }\end{array}$ & $\begin{array}{c}\text { Average } \\
\text { members / } \\
\text { family }\end{array}$ & $\begin{array}{c}\text { Average } \\
\text { members / } \\
\text { family }\end{array}$ & $\begin{array}{c}\text { Average } \\
\text { members / } \\
\text { family }\end{array}$ & $\begin{array}{c}\text { Average } \\
\text { members / } \\
\text { family }\end{array}$ \\
\hline District & 4.7 & 4.0 & 4.3 & 4.1 & 4.1 & -20.3 \\
\hline Gjirokaster. & 4.4 & 4.0 & 4.3 & 4.0 & 4.0 & -12.3 \\
\hline Permet & 4.6 & 4.0 & 4.1 & 4.0 & 4.2 & -26.2 \\
\hline Tepelene & 4.9 & 4.0 & 4.3 & 4.3 & 3.9 & -27.2 \\
\hline
\end{tabular}

Changes in the size of the family in this district reflect the situation of this decline in towns, cities and villages.

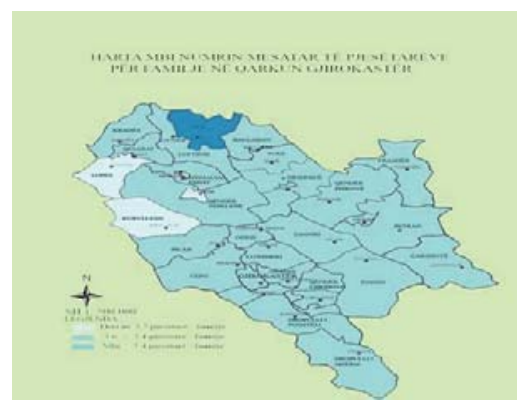

Picture 2. The map of average members / family. [3]

\section{The Results of this Analysis}

During 1990-s, the analysis about the structure of family size shows:

- The process of "distribution" of large families, with over 6 family members constitutes (by INSTAT) consist in $17.6 \%$ of the whole number of families in the region.

- This trend appears to be different among districts. In Tepelenë for instance very large families continues to be the majority of the family numbers, especially in the countryside where they occupy $26.7 \%$ of the total number of families (in the village). This shows that the tradition for a big family in this population is still strong.

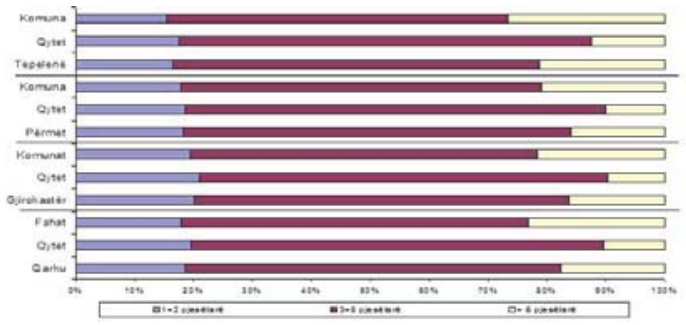

Picture 3. Families according the number of the members in Gjirokastra region $\left.{ }^{4}\right]$ 
- The number of small families with 1 - 2 family members consists in $18.6 \%$ in comparison to the total number of families in the region.

- The largest number of very small families with 1 to 2 people are those in Gjirokastra district due to the immigration of a massive population to Greece.

- In the first place stand families with two children constitute about $77.0 \%$ of the total number of families in the district of Gjirokastra.

- In second place stand families with 3 to 5 children and those with over 6 children who consist in less than $1.0 \%(0.7 \%)$ of the total number of families in the region.

The disintegration of large families and their replacement with smaller families with up to 2 members is due to changes that occurred in Albania after the collapse of the socialist system and extensive development (labor force growth by increasing the population).

Factors such are:

$\checkmark$ The transition from central planned socialist economy into a free market economy

$\checkmark$ economic crisis in the late 1980s,

$\checkmark$ increase in unemployment,

$\checkmark$ reduction of incomes,

$\checkmark$ private ownership, family planning, reduction in birth rate by half

$\checkmark$ influx of population in cities,

$\checkmark$ abandonment of the villages

$\checkmark$ the continuation of the immigration

$\checkmark$ the ageing population,

$\checkmark$ the decay gender equilibrium (male immigration),

$\checkmark$ weakening of the traditional psychology,

$\checkmark$ increased economic uncertainty,

All these were main factors that brought significant change in the performance and features of the Albanian family.

\section{References}

Doka Dhimitër Zhvillime socio-ekonomike dhe rajonale të Shqipërisë gjatë periudhës së tranzicionit Potsdam-Gjermani, 2005.

Dumani B. Statusi i zhvillimeve demo-ekonomike dhe sociale të

Dumani B.StringaA. Elemente të demografisë(Popullsia dhe zhvillimi)

INSTAT, zyrat arkivore te rretheve Gjirokaster, Permet, Tepelene

INSTAT Popullsia e Shqipërisë në 2001.Rezultatet e rregjistrimit të popullsisë dhe Banesave.

Popullsisë Buletin Nr.2 Tiranë,1995.

Popullsisë në pellgun e Mesdheut dhe Evropën Lindore. Studimet e

Studime gjeografike 2. Tiranë, 1987

Sheri F. Fjalori i enciklopedik demografisë. Botimet enciklopedike

Sheri F. Ndryshime gjeografike në lëvizjen natyrore të popullsisë. Tiranë, 1997. 